\title{
A NOTE ON THE CROSS-SECTION OF STOCK RETURNS ON THE ISTANBUL STOCK EXCHANGE*
}

\author{
N. VOLKAN KAYAÇETIN** \\ University of Alberta School of Business
}

\author{
Z. NURAY GÜNER*** \\ Middle East Technical University
}

\begin{abstract}
This paper investigates the explanatory powers of firm size, book-to-market, sales-to-price, debt-toequity ratio, and dividend yield on the cross-section of returns on the Istanbul Stock Exchange (ISE). Our results indicate that each of these variables (except dividend yield), commands a significant return premium when included in a simple regression model with the highest premium being associated with sales-to-price ratio. Our results suggest that sales-to-price ratio and debt-to-equity ratio have higher explanatory powers on the cross-sectional variability of returns on the ISE than firm size and book-tomarket ratio, firm-specific variables that are documented to have the greatest explanatory power on the cross-section of U.S. stock returns (Fama and French, 1992).
\end{abstract}

Key words: stock returns, Fama-French factors, Istanbul Stock Exchange.

\section{ISTANBUL MENKUL KIYMETLER BORSASI'NDA HISSSE SENEDİ GELIRLERI ÜZERINE BIR NOT}

\section{ÖZET}

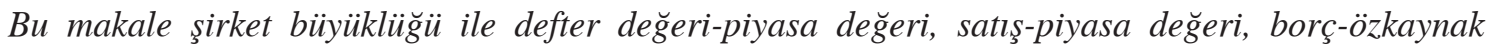
ve temettü verim oranlarının İstanbul Menkul Kıymetler Piyasası'nda (IMKB) işlem gören hisse senetlerinin getirilerini açıklama gücünü incelemektedir. Analizlerimiz temettü verim oranı dışındaki bütün değisskenlerin tek başlarına regresyona dahil edildiklerinde hisse senedi getirileri üzerinde önemli etkileri bulunduğu ve en yüksek etkinin satıs-fiyat oranına ait olduğu sonucunu vermistir. Bununla beraber, bulgularımız satış-fiyat ve borç-özkaynak oranlarının IMKB hisse senedi getirilerini, uluslararası literatürde zaman kesiti değişkenliğini açıklamada önemli adledilen şirket büyüklüğ̈̈ ve defter de ğeri-piyasa de ğeri oranına (Fama ve French, 1992) göre, daha iyi açıkladı̆̆ını göstermektedir.

Anahtar kelimeler: hisse senedi getirileri, Fama-French faktörleri, İstanbul Menkul Kıymetler Borsası

* Z. Nuray Güner, would like to acknowledge the support of the Turkish Academy of Sciences in the framework of the Young Scientist Award Program. (EA-TÜBA-GEBIP/2001-1-1). This paper is part of Mr. Kayaçetin's MBA thesis. The paper benefited significantly from the comments of participants of the Global Business and Technology Association's meetings in 2004 in Cape Town, South Africa.

** N. Volkan Kayaçetin is a doctoral candidate in the Department of Finance and Management Science at the University of Alberta School of Business, Edmonton, AB, Canada. E-mail: volkan@ualberta.ca

*** The corresponding author, Z. Nuray Güner is an Associate Professor in the Department of Business Administration at Middle East Technical University, İnönü Bulvarı, 06531, Ankara, Turkey. E-mail: nguner@ba.metu.edu.tr 
Fama and French (1992) show that two firm-specific variables, size and $B E / M E$, capture the crosssectional variation in stock returns quite well and subsume the explanatory power of earnings-toprice ratio, leverage, and market beta. Allowing for variation in beta unrelated to size, the authors demonstrate that the relation between market beta and average return is flat, a finding that has had a great impact on both academic and non-academic frontiers of finance. Particularly, the three-factor model introduced by Fama and French $(1993,1996)$, which includes the excess market return, the return on a portfolio long on small stocks and short on big stocks (SMB), and the return on a portfolio that has a long position in high book-to-market stocks and a short position in low book-to-market stocks $(H M L)$, now plays an integral part in many asset-pricing tests.

This paper examines the explanatory powers of firm size, book-to-market, sales-to-price (and gross profitto-price), debt-to-equity, and dividend yield for the cross-section of returns on the Istanbul Stock Exchange (ISE) in a period from July 1993 to December 2002. One important reason to conduct such a study is the fact that emerging markets display very different characteristics compared to those of established markets, such as the New York Stock Exchange or Tokyo Stock Exchange. In particular, emerging markets offer higher yields, have higher return volatilities, and demonstrate auto-correlated returns that are not integrated to global markets (Muradoğlu, Taşkın and Bigan, 2000). These differences, coupled with the crisis-prone nature of the Turkish economy, ${ }^{(1)}$ may alter the set of factors that proxy for equity risk. Specifically, we expect (i) firm leverages to have a more pronounced effect on the cross-section of returns due to increased bankruptcy risk in an unstable economic environment and (ii) book-to-market ratio to have lower explanatory power than cash flow-multiples like sales-to-price ratio, since high inflation rates will make book values of firm assets far less informative compared to established markets.

We conduct univariate tests of mean differences and Fama-MacBeth regressions and run a horse-race between the set of variables under study. Our results indicate that each of these variables (except dividend yield) has significant explanatory power for the cross-section of security returns on the ISE securities. Consistent with our expectations, the highest premiums are associated with sales-to-price ratio and debt-to-equity ratio, while the explanatory powers of firm size and book-to-market ratio for the cross-section of returns are subsumed by these two variables.

By examining the explanatory power of a larger set of company-specific variables over a longer time period, our paper expands on the results of a previous study by Akdeniz, Altay-Salih, and Aydoğan (2000), in which size and book-to-market are found to explain the cross-section of returns on the ISE and subsume the explanatory powers of market beta and earnings-to-price ratio in absence of sales-toprice and debt-to-equity ratios. To the best of our knowledge, sales-to-price, gross profit-to-price and debt-to-equity ratios have not yet been tested for the ISE securities.

The rest of the paper is organized as follows. The next section summarizes the relevant literature, followed by a description of our data and methodology. The next section provides a discussion of our results. The final section has our conclusions.

\section{RELEVANT LITERATURE AND CONTRIBUTIONS}

A particularly rich subject area in financial research relates to the way capital assets are priced in the market. From the 1950s until the present, financial researchers have tried a variety of approaches to tackle the asset-pricing puzzle. However, the complex stochastic processes associated with 
fundamentals, i.e., interest rates, and expected asset returns, render this puzzle difficult to solve.

The first and probably the most influential step was taken when Sharpe (1964), Lintner (1965), and Black (1972) introduced the Capital Asset Pricing Model (CAPM). The CAPM suggests that in a oneperiod economy in which investors follow the mean-variance optimization principles of Markowitz (1952), everyone will hold a mixture of the risk-free asset and a market portfolio, and that the returns on securities will be explained by the market beta $(\beta)$, which measures the sensitivity of asset returns to the return on the market as a whole.

The CAPM provides a simple and elegant framework in which asset returns can be studied; but in doing so, it requires very stringent assumptions to hold. The model's main premise that the $\beta$ should capture all the variation in security returns has constantly been called into question. A good number of firm-specific variables, including the dividend yield (Brennan, 1970), earnings-price ratio (Basu, 1977), firm size (Banz, 1981), book-to-market ratio (Stattman, 1980), financial leverage (Bhandari, 1988), sales-to-price ratio (Senchack and Martin, 1987), and cash flow-to-price ratio (Chan, Hamao, and Lakonishok, 1991), are shown to have significant explanatory powers on the cross-section of returns, over and above that of $\beta$. These findings, initially, are regarded as anomalies.

The Arbitrage Pricing Theory (APT) of Ross (1976) provides an alternative framework within which the puzzling significance of above listed firm-specific variables can be recognized. Assuming the individuals believe in a k-factor return-generating model, the APT suggests security returns may be represented as linear combinations of variables that are correlated with these $\mathrm{k}$ systematic risk sources. This implies that variables like size, book-to-market, and leverage may be factors correlated with the underlying risk sources.

An influential paper by Fama and French (1992) initiates the rise of size and book-to-market as important asset pricing factors. The authors show that these two specific variables explain the crosssection of returns well and subsume the explanatory power of $\beta$ and earnings-to-price ratio. It is also shown that, controlling for differences in size, the relation between $\beta$ and asset returns is flat. In two subsequent studies, Fama and French $(1993,1996)$ establish SMB and $H M L$ as the time-series factors for size and book-to-market and show that a three-factor model that also includes the excess market return (i) explains the average returns quite well and (ii) dismisses certain return anomalies related to size, book-to-market, earnings-to-price, and dividend yield.

The cross-section of returns on the ISE, an important emerging market, was previously investigated by Akdeniz, Altay-Salih, and Aydoğan (2000). The authors study average returns on ISE securities over the period from January 1992 to December 1998 and find, consistent with the results reported in Fama and French (1992), that size and book-to-market explain the cross-section of returns on the ISE and subsume the explanatory powers of market beta and earnings-to-price ratio. By analyzing and comparing the explanatory powers of a larger set of variables over a longer sample period, our paper expands on these results and provides additional insights.

\section{DATA AND METHODOLOGY}

Our sample includes all the firms that are listed on the ISE during the period from July 1992 to 2002 with the exception of financial firms, holdings, and firms with more than one type of share quoted 
on the market. ${ }^{(2)}$ As of the end of 1992, there were a total of 145 securities listed on the ISE. After taking out financial firms, holdings and firms with more than one type of share quoted on the market, our sample size reduces to 94 securities. For December 2002, our sample includes 204 securities. During our sample period, we have 19,487 firm months. The financial information required for a firm to be included in the cross-sectional regressions for the measurement period July t through June $t+1$ consists of the stock price $\left(P_{i, 6, t-1}\right)$ and number of shares outstanding $\left(N S O_{i, 6, y-1}\right)$ as of the end of June of year $t-1$, and annual dividends $\left(D I V_{i, t-1}\right)$, book value of total assets $\left(T A_{i, t-1}\right)$, book value of total equity $\left(T E_{i, t-1}\right)$, sales $\left(S_{i, t-1}\right)$, and cost of goods sold $\left(C_{i, t-1}\right)$ as reported in the December-end financial statements of year $t-1$. Therefore, the return data used in our analysis cover a period from July 1993 to December 2002. Data on monthly stock prices and number of shares outstanding are obtained from databases maintained by the ISE while data on accounting figures are from the database of financial statements of the ISE firms published on the official web site of the ISE (www.imkb.gov.tr).

Following Fama and French (1992), we calculate the market value of equity (MVE) for each firm in year $\mathrm{t}$ using the end of June values for NSO and stock prices in year $t-1$. The year $t$ values for book-to-market ratio $(B E / M E)$, sales-to-price ratio $(S / P)$, gross profit-to-price ratio $(G P / P)$, debt-toequity ratio $(D / E)$, and dividend yield $(D Y)$ are calculated using the December-end financial statement figures from year $t-1$ and the market value of equity at the end of June in year $t-1$. The market beta and earnings-to-price ratio are not included in the set of explanatory variables, based on the results reported in Akdeniz, Altay-Salih, and Aydoğan (2000) that these two variables fail to have any significant explanatory power on the cross-section of returns over that of $B E / M E$ and $M V E$. The six month lag between the measurement period and the date at which the information contained in explanatory variables are made public follows Fama and French (1992) and aims to avoid the potential look-ahead bias that might be induced by possible lags in firm's financial statement submissions. ${ }^{(3)}$ The firmspecific variables are defined as follows:

$$
\begin{aligned}
& M V E_{i, t}=P_{i, 6, t-1} * N S O_{i, 6, t-1} \\
& B E / M E_{i, t}=T E_{i, t-1} / M V E_{i, t-1} \\
& S / P_{i, t}=S_{i, t-1} / M V E_{i, t} \\
& G P / P_{i, t}=\left(S_{i, t}-C_{i, t}\right) / M V E_{i, t} \\
& D / E_{i, t}=\left(T A_{i, t}-T E_{i, t}\right) / T E_{i, t} \\
& D Y_{i, t}=D I V_{i, t-1} / P_{i, 12, t-1}
\end{aligned}
$$

\section{Univariate Analysis}

At the beginning of each measurement period (i.e., from July t to June $t+1$ ), the sample of stocks is sorted on the firm-specific factors $\left(X_{i t}\right)$, one at a time, and equally weighted portfolios of the top $30 \%$, the middle $40 \%$, and the bottom $30 \%$ of the ranked list are formed, which we refer to as high $(\mathrm{H})$, medium $(\mathrm{M})$, and low $(\mathrm{L})$ factor portfolios. The twelve-month measurement period returns on these portfolios and the portfolio averages of the firm-specific factors are computed. We calculate the differences between the returns on high and low factor $X$ portfolios $\left(R_{H X}-R_{L X}\right)$ and conduct a onetailed t-test to find out whether these differences verify our prior expectations on how these factors should be related to asset returns. The mean return differential calculated for factor $X$ is hereafter referred to as $H M L_{X}$. We also observe and report, for each factor, whether the returns on $\mathrm{H}, \mathrm{M}$, and $\mathrm{L}$ portfolios uniformly increase or decrease as we go from high to low values of the factor under study. 


\section{Fama-MacBeth Regressions}

The 12-month return measurement periods start on July 1 of each year $t$ and end on June 30 of year $t+1$. Following the Fama-MacBeth (1971) procedure, we run cross-sectional regressions of monthly returns observed over each measurement period on different combinations of firm-specific factors, which are computed using the previous year's accounting figures as described earlier. This procedure yields a total of $113^{(4)}$ coefficient estimates for each company-specific variable $\left(\beta_{X}\right)$ for each model tested. The time-series averages of the $\beta$ s are computed and tested using a simple t-test.

First, we run simple regressions of the returns on each firm-specific variable. The variables that fail to obtain significant coefficients in these models are eliminated from further analysis. Next, we run multiple regressions of the returns on all possible combinations of the remaining set of factors and compare the explanatory power of size and book-to-market to those of cash flow-to-price ratios $(S / P$ and $G P / P), D / E$ and $D / P$ by looking at (i) the significance of coefficient estimates for models in which the variables are used together and (ii) the time-series means of adjusted $\mathrm{R}^{2}$ for models in which the variables are used separately.

The next section presents a discussion of the results that we obtain from the univariate tests of mean differences across high and low factor portfolios and the Fama-MacBeth cross-sectional regressions.

\section{RESULTS AND DISCUSSION}

\section{Descriptive Statistics}

Panel A of Table 1 reports the time-series averages of the cross-sectional means for the firm-specific variables under examination for the market as a whole. For an average ISE firm, the average market capitalization is approximately 54 trillion TL during our sample period. Similarly, over the ten years under study, average book-to-market ratio, average sales-to-price ratio, average gross profit-to-price ratio, average debt-to-equity ratio and average dividend yield for an average ISE firm are 0.618, 1.498, $0.395,0.920$, and 0.2 , respectively.

Panel B of Table 1 presents the cross-sectional averages of the stock-level time-series correlations between the firm specific variables. All of the correlations, with the exception of those between dividend yield and other firm specific variables, are statistically significant at the one percent level. MVE is negatively related to $B E / M E, S / P, G P / P$ and $D / E$ with correlation coefficients ranging from -0.26 to -0.31 . $B E / M E, G P / P$, and $D / E$ are all positively related to each other. The correlations of 0.45 between $B E / M E$ and $D / E, 0.62$ between $S / P$ and $D / E$, and 0.53 between $D / E$ and $G P / P$ are worth noting. Returns display the highest correlation with $M V E$ (-0.268), followed by $S / P(0.216), G P / P(0.197)$, and $B E / M E(0.141)$. All of these correlation coefficients are statistically significant at the one percent level as well. Even though dividend yield is positively related to returns (0.006), statistically, the correlation coefficient is not significantly different from zero at any reasonable significance level. 
Table 1

Descriptive Statistics

Panel A: Means of Relevant Variables for Sample Firms

during the Sample Period

\begin{tabular}{lc}
\hline Variables & All Securities \\
\hline $\mathrm{MVE}^{*}\left(10^{9}\right)$ & \\
$\mathrm{BE} / \mathrm{ME}$ & 54,000 \\
$\mathrm{~S} / \mathrm{P}$ & 0.618 \\
$\mathrm{GP} / \mathrm{P}$ & 1.498 \\
$\mathrm{D} / \mathrm{E}$ & 0.395 \\
$\mathrm{DY}$ & 0.920 \\
\hline
\end{tabular}

Panel B: Correlation Coefficients

The correlation coefficients between subsequent returns, dividend yields, and natural logarithms of MVE, BMR, SPR, SCPR, and DER are reported for aggregate cross-sectional data. Return data covers a period from July 1993 to December 2002, while the accounting figures are derived from annual report data for a period from December 1992 to December 2001. The numbers in parentheses are $\mathrm{t}$-values calculated for these coefficients.

\begin{tabular}{|c|c|c|c|c|c|c|}
\hline & MVE & BE/ME & $\mathrm{S} / \mathrm{P}$ & GP/P & $\mathrm{D} / \mathrm{E}$ & DY \\
\hline BMR & $\begin{array}{c}\mathbf{- 0 . 2 7 8} \\
(-11.15)\end{array}$ & & & & & \\
\hline SPR & $\begin{array}{c}\mathbf{- 0 . 2 5 7} \\
(-10.26)\end{array}$ & $\begin{array}{c}\mathbf{0 . 2 8 6} \\
(11.49)\end{array}$ & & & & \\
\hline SCPR & $\begin{array}{c}\mathbf{- 0 . 3 0 9} \\
(-12.51)\end{array}$ & $\begin{array}{l}\mathbf{0 . 2 4 6} \\
(9.79)\end{array}$ & $\begin{array}{c}\mathbf{0 . 8 0 2} \\
(51.81)\end{array}$ & & & \\
\hline DER & $\begin{array}{c}-\mathbf{- 0 . 2 5 7} \\
(-10.27)\end{array}$ & $\begin{array}{c}\mathbf{0 . 4 5 1} \\
(19.45)\end{array}$ & $\begin{array}{c}\mathbf{0 . 6 1 6} \\
(30.13)\end{array}$ & $\begin{array}{c}\mathbf{0 . 5 3 0} \\
(24.07)\end{array}$ & & \\
\hline DY & $\begin{array}{l}-\mathbf{0 . 0 0 1} \\
(-0.05)\end{array}$ & $\begin{array}{l}\mathbf{- 0 . 0 4 8} \\
(-1.87)\end{array}$ & $\begin{array}{l}\mathbf{- 0 . 0 3 1} \\
(-1.19)\end{array}$ & $\begin{array}{l}\mathbf{- 0 . 0 1 4} \\
(-0.53)\end{array}$ & $\begin{array}{l}\mathbf{- 0 . 0 6 1} \\
(-2.34)\end{array}$ & \\
\hline Return & $\begin{array}{c}\mathbf{- 0 . 2 6 8} \\
(-10.72)\end{array}$ & $\begin{array}{l}\mathbf{0 . 1 5 7} \\
(6.13)\end{array}$ & $\begin{array}{l}\mathbf{0 . 2 1 6} \\
(8.53)\end{array}$ & $\begin{array}{l}\mathbf{0 . 1 9 7} \\
(7.74)\end{array}$ & $\begin{array}{l}\mathbf{0 . 1 4 1} \\
(5.49)\end{array}$ & $\begin{array}{l}\mathbf{0 . 0 0 6} \\
(0.25)\end{array}$ \\
\hline
\end{tabular}




\section{Univariate Analysis}

The first stage of our study entails a preliminary analysis of the returns on high, medium, and low factor portfolios formed on each of the company specific factors under study. The statistical tool used in this part of the analysis is a simple one-tailed t-test performed on annual return differentials between high and low factor portfolios. The results are presented in panels A to F of Table 2.

Table 2

Results of Univariate Portfolio Analysis

Reported in the panels below are the ten-year averages of the annual returns observed on the high, medium, and low portfolios formed through one-way sorts performed for each company-specific variable under study, presented together with the average values of that company-specific variable on which the portfolio is formed. HML is the return differential between high and low portfolios. $\mathrm{t}$-values obtained from one-tailed tests of our preliminary hypotheses performed on these return differentials, and the p-values associated with these tests are also given.

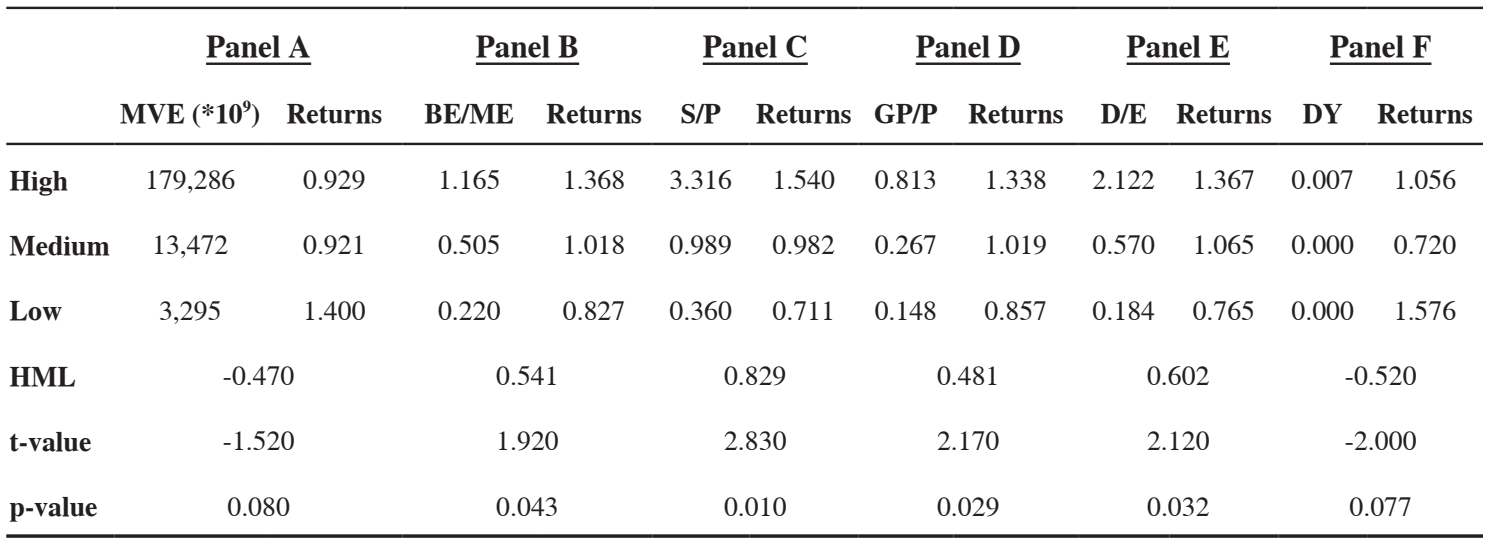

Before interpreting these results, we have to note that the $\mathrm{t}$ - and p-values reported might not constitute, by themselves, enough evidence on the nature of the actual relation between returns and a tested variable due to the small size of our sample. Nevertheless, when the patterns displayed by returns on high, medium, and low factor portfolios are combined with the respective t-statistics of the mean return differences between $\mathrm{H}$ and $\mathrm{L}$ portfolios, it might be possible to obtain a general picture of the nature of the relation between returns and the firm-specific variables. With this in mind, we proceed to discuss the results.

For all variables, except dividend yield, the differences between the returns on high and low factor portfolios confirm our prior expectations. Consistent with the existing evidence, asset returns are negatively related to firm size and positively related to book-to-market, sales-to-price, gross profitto-price, and debt-to-equity ratios. The dividend yield, on the other hand, demonstrates a negative return differential, a finding that contradicts the general wisdom in financial research. All of the 
relations are significant at the $10 \%$ level. Among the firm-specific variables, S/P commands the highest absolute annual return differential $(82.9 \%)$, followed by debt-to-equity ratio $(60.2 \%)$, and book-to-market ratio $(54.1 \%)$.

Examining the patterns of returns for high, medium, and low factor portfolios, we may be able to get a preliminary notion on whether these factors are related linearly to average annual returns. All portfolios except those formed on firm size and dividend yield display a monotonic pattern with returns increasing as we go from low to high factor portfolios. The violation of the monotonic pattern for size and dividend yield may be viewed as a signal of a non-linear relation between returns and these variables. Furthermore, means reported for the H, M, and L portfolios confirm that our sorts resulted in a reasonable degree of heterogeneity to study the effects of these firm characteristics on the crosssection of returns.

\section{Fama-MacBeth Regressions}

In the second stage of our study, we conduct cross-sectional regressions of stock returns on company specific variables. The analysis is made using the well-known Fama-MacBeth cross-sectional regression methodology. The average monthly coefficients for each different model are tested and the t-values associated with these coefficients are presented in Table 3.

The coefficients obtained from single-parameter cross-sectional regressions of returns on companyspecific factors, and t-values associated with these coefficients are reported in Panel A of Table 3. All factors, except dividend yield, have a statistically significant coefficient at a 95\% confidence level. Since dividend yield has a statistically insignificant coefficient even when used alone in a regression, this variable is excluded from further analysis. Based on the magnitude of regression coefficients, their significances, and adjusted R-square values, we also decide that, of the two earnings measures, the sales-to-price ratio is superior to the gross profit-to-price ratio. Furthermore, the sales-to-price ratio is less prone to manipulation by management. In line with our a priori expectations, and as confirmed by preliminary portfolio analysis, firm size has a negative coefficient (-0.006), while positive coefficients are obtained for book-to-market ratio (0.010), sales-to-price ratio (0.014), gross profit-to-price ratio (0.012), and debt-to-equity ratio (0.010).

Table 3

Fama-MacBeth Cross-Sectional Regression Coefficients

Results are based on an Ordinary Least Squares model. The full model is:

$$
R_{i}=\gamma_{0}+\gamma_{1} \ln M V E_{i}+\gamma_{2} \ln B E / M E_{i}+\gamma_{3} \ln S / P_{i}+\gamma_{4} \ln G P / P_{i}+\gamma_{5} \ln D / E_{i}+\gamma_{6} D Y_{i}
$$

$\mathrm{R}_{\mathrm{i}}$ is the monthly return on security $\mathrm{i}$; $\operatorname{lnMVE}, \operatorname{lnBE} / \mathrm{ME}_{\mathrm{i}}, \ln \mathrm{l} / \mathrm{P}_{\mathrm{i}}$, $\operatorname{lnGP} / \mathrm{P}_{i}$ and $\operatorname{lnD} / \mathrm{E}_{\mathrm{i}}$, are the natural logarithms of firm size, bookto-market ratio, sales-to-price ratio, gross profit-to-price ratio, and debt-to-equity ratio, respectively; DY is the dividend yield. The average single-parameter, two-parameter, and multi-parameter regression coefficients are reported, respectively, in Panel A, Panel $\mathrm{B}$, and Panel C. The numbers in parentheses are the t-values. Average R-square values for different models are also reported in the last column. 
Table 3 (continued)

\begin{tabular}{|c|c|c|c|c|c|c|c|}
\hline \multicolumn{8}{|c|}{ Panel A } \\
\hline Model & MVE & BE/ME & $\mathbf{S} / \mathbf{P}$ & GP/P & $\mathrm{D} / \mathrm{E}$ & DY & $\mathbf{R}^{2}$ \\
\hline 1 & $\begin{array}{c}\mathbf{- 0 . 0 0 6} \\
(-2.297)\end{array}$ & & & & & & 0.032 \\
\hline 2 & & $\begin{array}{c}\mathbf{0 . 0 1 0} \\
(2.240)\end{array}$ & & & & & 0.022 \\
\hline 3 & & & $\begin{array}{c}\mathbf{0 . 0 1 4} \\
(4.093)\end{array}$ & & & & 0,022 \\
\hline 4 & & & & $\begin{array}{c}\mathbf{0 . 0 1 2} \\
(3.638)\end{array}$ & & & 0.017 \\
\hline 5 & & & & & $\begin{array}{c}\mathbf{0 . 0 1 0} \\
(3.329)\end{array}$ & & 0.023 \\
\hline 6 & & & & & & $\begin{array}{c}\mathbf{1 . 7 4 2} \\
(1.031)\end{array}$ & 0.011 \\
\hline
\end{tabular}

\begin{tabular}{|c|c|c|c|c|c|c|c|}
\hline \multicolumn{8}{|c|}{ Panel B } \\
\hline Model & MVE & BE/ME & $\mathbf{S} / \mathbf{P}$ & GP/P & $\mathrm{D} / \mathrm{E}$ & DY & $\mathbf{R}^{2}$ \\
\hline 7 & $\begin{array}{c}\mathbf{- 0 . 0 0 5} \\
(-1.708)\end{array}$ & $\begin{array}{c}\mathbf{0 . 0 0 5} \\
(1.262)\end{array}$ & & & & & 0.045 \\
\hline 8 & $\begin{array}{c}\mathbf{- 0 . 0 0 2} \\
(-0.696)\end{array}$ & & $\begin{array}{c}\mathbf{0 . 0 1 2} \\
(3.419)\end{array}$ & & & & 0.043 \\
\hline 9 & $\begin{array}{c}\mathbf{- 0 . 0 0 4} \\
(-1.376)\end{array}$ & & & & $\begin{array}{c}\mathbf{0 . 0 0 7} \\
(2.544)\end{array}$ & & 0.042 \\
\hline 10 & & $\begin{array}{c}\mathbf{0 . 0 0 5} \\
(1.330)\end{array}$ & $\begin{array}{c}\mathbf{0 . 0 1 3} \\
(4.332)\end{array}$ & & & & 0.032 \\
\hline 11 & & $\begin{array}{c}\mathbf{0 . 0 0 5} \\
(1.273)\end{array}$ & & & $\begin{array}{c}\mathbf{0 . 0 0 8} \\
(2.966)\end{array}$ & & 0.032 \\
\hline 12 & & & $\begin{array}{r}\mathbf{0 . 0 1 2} \\
(3.334) \\
\end{array}$ & & $\begin{array}{c}\mathbf{0 . 0 0 2} \\
(0.571) \\
\end{array}$ & & 0.029 \\
\hline & & & & anel C & & & \\
\hline Model & MVE & BE/ME & $\mathbf{S} / \mathbf{P}$ & GP/P & $\mathrm{D} / \mathrm{E}$ & DY & $\mathbf{R}^{2}$ \\
\hline 13 & $\begin{array}{c}\mathbf{- 0 . 0 0 2} \\
(-0.704)\end{array}$ & $\begin{array}{c}\mathbf{0 . 0 0 4} \\
(1.126)\end{array}$ & $\begin{array}{c}\mathbf{0 . 0 1 2} \\
(3.597)\end{array}$ & & & & 0.051 \\
\hline 14 & $\begin{array}{c}\mathbf{- 0 . 0 0 3} \\
(-1.015)\end{array}$ & & $\begin{array}{c}\mathbf{0 . 0 1 1} \\
(2.788)\end{array}$ & & $\begin{array}{c}\mathbf{0 . 0 0 2} \\
(0.578)\end{array}$ & & 0.046 \\
\hline 15 & $\begin{array}{c}\mathbf{- 0 . 0 0 4} \\
(-1.509)\end{array}$ & $\begin{array}{c}\mathbf{0 . 0 0 4} \\
(0.932)\end{array}$ & & & $\begin{array}{c}\mathbf{0 . 0 0 6} \\
(2.347)\end{array}$ & & 0.049 \\
\hline 16 & & $\begin{array}{c}\mathbf{0 . 0 0 7} \\
(1.659)\end{array}$ & $\begin{array}{c}\mathbf{0 . 0 1 3} \\
(3.438)\end{array}$ & & $\begin{array}{c}\mathbf{0 . 0 0 0} \\
(-0.004)\end{array}$ & & 0.036 \\
\hline 17 & $\begin{array}{c}\mathbf{- 0 . 0 0 2} \\
(-0.818) \\
\end{array}$ & $\begin{array}{c}\mathbf{0 . 0 0 5} \\
(1.161) \\
\end{array}$ & $\begin{array}{c}\mathbf{0 . 0 1 2} \\
(2.870) \\
\end{array}$ & & $\begin{array}{c}\mathbf{0 . 0 0 0} \\
(-0.057) \\
\end{array}$ & & 0.055 \\
\hline
\end{tabular}


The results of the two-parameter regressions are presented in Panel B of Table 3. In these regressions, we find out that the coefficients of firm size and book-to-market ratio lose their statistical significance when sales-to-price ratio or debt-to-equity ratio is added to the model. ${ }^{(5)}$ Sales-to-price and debt-toequity ratios, on the other hand, display statistically significant coefficients when used together with either firm size or book-to-market ratios. The coefficient for sales-to-price ratio ranges between 0.012 and 0.013 in two parameter regressions. Debt-to-equity ratio, on the other hand, maintains a statistically significant coefficient between 0.007 and 0.008 , except in the model that it is used together with salesto-price ratio. In this model, the debt-to-equity ratio loses its statistical significance.

The results of three- and four-factor models are presented in Panel C of Table 3. These results support the conclusions we drew in the previous paragraph. With coefficients that range between 0.011 and 0.013 , the sales-to-price ratio is the only variable that retained its statistical significance in all the models studied. Our measure of financial leverage, i.e., debt-to-equity ratio, has promising results except for the models in which it is used together with sales-to-price ratio. Contrary to the evidence from studies conducted on established stock markets, neither the firm size nor the book-to-market ratio seem to have any explanatory power for the cross-section of returns on the ISE when the sales-to-price ratio is included in the model.

The finding that the explanatory power of $B E / M E$ is subsumed by $S / P$ is interesting given the stylized empirical evidence in the literature in favor of this factor, but not very surprising when viewed in the context of the Turkish economy. Indeed, one may expect the high inflation rates experienced in the country during the early part of our sample period and the partial inflation adjustment in the accounting books of companies during our sample period to reduce the meaningfulness of the book equity figures. As a result, these two factors might result in reduced explanatory power for the book-to-market ratio. $S / P$, on the other hand, is relatively more robust to the distortion caused by high inflation rates.

Ultimately, our thesis is that $S / P$ captures the same underlying risk factor - financial distress (or behavioral bias, depending on reader's beliefs) as BE/ME in the Fama and French (1996) three-factor model, without being subject to the adverse effect of inflation on the book value of assets. This line of reasoning, however, does not apply to firm size, which is also subsumed by $S / P$ and $D / E$. A plausible explanation is that, given the low market capitalization and high proportion of speculative trades on the ISE, and the fragility of the Turkish economy, investors might care more about whether there is demand for the product of a company (short-term stability captured by the sales-to-price ratio) and whether the firm is bankruptcy-prone (leverage captured by the debt-to-equity ratio) than how big the market capitalization of the company is.

\section{CONCLUSIONS}

In this paper, the explanatory powers of firm size, book-to-market ratio, sales-to-price ratio, gross profit-to-price ratio, debt-to-equity ratio, and dividend yield for the cross-section of returns on the Istanbul Stock Exchange were examined. Our sample spanned a 114-month time period starting from July 1993 to December 2002, resulting in 113 return observations. In the end, we found that, by themselves, all of these company-specific variables, except dividend yield, commanded statistically significant premia on returns. 
Using market capitalization as a proxy for the firm size, we showed that a significant negative relationship exists between returns and firm size. The relationship between book-to-market ratio and returns, on the other hand, was positive and statistically significant. The coefficients found in the single-parameter Fama-MacBeth regressions for firm size and book to market ratio were -0.006 and 0.010 , respectively. These values are very close to the respective coefficients reported in a similar study conducted on the ISE by Akdeniz et al. (2000).

Sales-to-price ratio and debt-to-equity ratio are two company specific variables that, to the best of our knowledge, have not yet been tested for the ISE. We tested the explanatory powers of these variables and found a positive and statistically significant relationship between returns and these variables. Both debt-to-equity ratio and sales-to-price ratio subsumed the explanatory powers of firm size and bookto-market ratio when used together in regression models that contain either, or both, of these variables. Based on this finding, we reached the conclusion that sales-to-price and debt-to-equity ratios could do a better job in capturing the cross-sectional variability of returns on the ISE compared to firm size and book-to-market ratio.

The gross profit-to-price ratio was also tested and its explanatory power was found to be inferior to that of the sales-to-price ratio. The cost of goods sold figures includes the depreciation related to manufacturing facilities. The inclusion of manipulation-prone depreciation account in calculation of cost of goods sold might cause such a decrease in the explanatory power of gross profit-to-price ratio.

Of all the variables tested, sales-to-price ratio was the most powerful. The univariate portfolio analysis results indicated that the highest return premium was associated with $S / P$. Furthermore, Fama-MacBeth regression results agreed on a relatively robust coefficient for $S / P$, which ranged between 0.011 and 0.014. Moreover, the sales-to-price ratio subsumed the statistical significances of all other variables under study when used together in multi-factor Fama-MacBeth regressions. These results on the interrelationship between firm size, book-to-market ratio, sales-to-price ratio, and debt-to-equity ratio comply one-to-one with the results of a study by Barbee, Mukherji, and Reines (1996).

Unfortunately, our study has some limitations. One of these limitations is that market betas are not included in our analysis. Since Akdeniz et al. (2000) find insignificant explanatory power for market betas on the ISE during the period from 1992 to 1998, this exclusion of the market factor may not be that problematic. Also, we have to work with a much smaller sample of returns compared to the tests conducted on established markets such as the New York Stock Exchange or the Tokyo Stock Exchange. The power of our tests, hence, is negatively effected by the size of our sample.

There is still much more to do to understand the behavior of returns on the Istanbul Stock Exchange. Although our study addresses only some company-specific factors, models that contain a combination of external factors (like general economic activity as well as industry-specific factors), extracted factors (like market beta) and company-specific factors (like sales-to-price ratio) might do a better job in explaining the cross-sectional variability in returns. 


\section{NOTES}

1. The Turkish economy suffered financial crises in 1994, 1997, 2000 and 2001.

2. Financial firms are excluded since characteristically the high debt-to-equity ratios of such firms do not necessarily indicate financial distress, and hence, may distort our analysis. Holdings are excluded, as the stocks of such companies resemble more a mini-portfolio than a single security. Firms with more than one type of share quoted on the stock market are also taken out of the sample since a high correlation among returns to these securities is expected.

3. Companies listed on the ISE are obliged to report their financial statements to the Capital Market Board (CMB) and the ISE within three months after their fiscal year end. However, more than rarely, extensions, which may take as long as three more months, can be granted to this preset deadline. A six-month lag between the computations of firm returns and company specific variables is, thus, seen appropriate in order to avoid a look-ahead bias. This six-month lag is also consistent with lags used in earlier studies (Fama and French [1992, 1993, 1995], Kothari et al. [1995], Akdeniz et al. [2000]).

4. The price data used start from July 1993 and ends at December 2002, resulting in 113 return measurements.

5. Results with gross profit-to-sales ratio are essentially the same, but to conserve space they are not reported here. However, these results are available from the authors upon request.

\section{REFERENCES}

Akdeniz, L., Altay-Salih, A., and Aydoğan, K. (2000). "Cross-Section of Expected Stock Returns on the Istanbul Stock Exchange," Russian and East European Finance and Trade, 36: 6-26.

Basu, S. (1977). "Investment Performance of Common Stocks in Relation to their Price-Earnings Ratios: A Test of the Efficient Market Hypothesis,"Journal of Finance, 32: 663-682.

Banz, R.W. (1981). “The Relationship between Return and Market Value of Common Stocks,” Journal of Financial Economics, 9: 3-18.

Barbee, W.C., Mukherji, S., and Reines, G.A. (1996). "Do Sales-Price and Debt-Equity Explain Stock Returns Better than Book-Market and Firm Size?” Financial Analysts Journal, March/April: 56-60.

Bhandari, L.C. (1988). "Debt/Equity Ratio and Expected Common Stock Returns: Empirical Evidence," Journal of Finance, 43: 507-528.

Black, F. (1972). "Capital Market Equilibrium with Restricted Borrowing," Journal of Business, 45: 444-454. 
Brennan, M.J. (1970). "Investor Taxes, Market Equilibrium, and Corporation Finance," Ph.D. Dissertation (Massachusetts Institute of Technology, Cambridge, Massachusetts).

Chan, K.C., Hamao, Y., and Lakonishok, J. (1991). “Fundamentals and Stock Returns in Japan,”,Journal of Finance, 46(5):1739-1764.

Fama, E.F. and French, K.R. (1992). "The Cross-Section of Expected Stock Returns," Journal of Finance, 47: 427- 465.

----- (1993). "Common Risk Factors in the Returns on Stocks and Bonds," Journal of Financial Economics, 33, 3-56.

----- (1996). “Multifactor Explanations of Asset Pricing Anomalies,” Journal of Finance, 51(1): 5584.

Lintner, J. (1965). "The Valuation of Risk Assets and Selection of Risky Investments in Stock Portfolios and Capital Budgets," Review of Economics and Statistics, 47: 13-37.

Markowitz, H. (1952). "Portfolio Selection,” Journal of Finance, 7: 77-91.

Merton, R.C. (1973). “An Intertemporal Capital Asset Pricing,” Econometrica, 41: 867-887.

Mossin, J. “Equilibrium in a Capital Asset Market,” Econometrica, 34: 768-783.

Muradoğlu, G., Taşkın, F., and Bigan, I. (2000). "Causality of Stock Returns and Macroeconomic Variables in Emerging Markets," Russian and East European Finance and Trade, 36. 33-53.

Ross, S.A. (1976). “The Arbitrage Theory of Capital Asset Pricing," Journal of Economic Theory, 13. 341-360.

Senchack, A., Martin, J. (1987). "The Relative Performance of the PSR and PER Investment Strategies," Financial Analysts Journal, 43. 45-66.

Sharpe, W. (1964). "Capital Asset Prices: A Theory of Market Equilibrium under Conditions of Risk," Journal of Finance, 19: 425-442.

Stattman, D. (1980). "Book Value and Stock Returns," The Chicago MBA, 4. 